\title{
IMPACT OF MACROECONOMIC BEHAVIOUR ON DEPOSIT MONEY BANK LIQUIDITY IN NIGERIA
}

\author{
Topbie, Joseph Akeerebarii, \\ Fiberesima Ibiwari, \\ Nwankwo, Godgift Anyamaobi \\ Department Of Economics, \\ University of Port Harcourt, \\ Choba, Rivers State, \\ Nigeria
}

\begin{abstract}
:
According to Keynes (1936), money is the most liquid asset. Liquidity is an attribute to an asset. The more quickly an asset is converted into money the more liquid it is said to be. Purpose: this study was carried out to determine the long-run and short-run impact of macroeconomic behaviour as measured by money supply, exchange rate, real interest rate, and credit to the private sector on deposit money bank liquidity in Nigeria as measured by liquidity ratio; using annual time-series data ranging from 1990 to 2020 . Methodology/Technique: the purpose of this study was achieved by the application of Autoregressive Distributed Lag Technique (ARDL) together with Augmented DickeyFuller and Phillip-Peron Tests. Findings: it was revealed that the liquidity ratio converged with $3.17 \%$ to long-run equilibrium after a shock to explanatory variables. It further displayed that the current level of money supply and real interest rate had a negative but significant impact on liquidity ratio, whereas, one-year lag and two-year lag of money supply, real interest rate, and exchange rat positively impacted liquidity ratio in both long-run and short-run. Conversely, it was revealed that one-year lag, two-year lag, and three-year lag of credit to the private sector had a negative and insignificant impact on liquidity ratio in the long-run, while it negatively and significantly impacted liquidity ratio in the short-run. Conclusion/Policy Recommendations: As a result of the findings, the study recommended that government policies that will enforce sustainable and efficient liquidity ratio be made feasible in the banking sector.
\end{abstract}

JEL: E10; E20; E40

Keywords: macro-economic behaviour, liquidity ratio, liquidity preference theory, ARDL co-integration, ARDL long-run and short-run

${ }^{i}$ Correspondence: email topbiejoseph@yahoo.com 


\section{Introduction}

When it comes to influencing the economy via macroeconomic behaviour of fiscal and monetary policies. Government typically relies on fiscal policies as a tool to steer the economy to a desired direction - government influences the economy by changing the level and types of taxes, the degree and form of borrowing, and the extent of spending. Whereas, the monetary authority - central bank indirectly target activity by influencing the money supply through adjustments to bank reserve requirements, interest rates, and the purchase and sale of government securities and foreign exchange. Hence, it can be seen that the ultimate goal of both policies is to ensure macroeconomic stability which is required for repositioning financial markets on a sustainable growth trajectory (Hsing, 2013). In every system, there are major components that feature paramount for the survival of the system. This is also applicable to the financial system. The banking institution had contributed significantly to the effectiveness of the entire financial system as they offer an efficient institutional mechanism through which resources can be mobilized and directed from less essential uses to more productive investments (Wilner, 2000). In view of this role, and of the fact that the activities of the deposit money banks affect the greater part of the society - deposit money bank's liquidity is selected as the main focus of this study. An adequate financial intermediation requires the purposeful attention of the bank management to liquidity, which is one of the two conflicting goals of the commercial banks. These goals are parallel in the sense that an attempt for a bank to achieve higher profitability will certainly erode its liquidity and solvency positions and vice versa. Practically, profitability and liquidity are effective indicators of the corporate health and performance of not only the commercial banks (Eljelly, 2004), but all profitoriented ventures. Over the years, liquidity has been one of the major challenges hindering the stability of banks in Nigeria due to their reliance on central bank credits as their major sources of funding. As a result, many attempts by the banking regulators to ensure stability and sustainability of the banking industry have not achieved targeted objectives (Sanusi, 2011; Soludo, 2004). On the other hand, the banks in Nigeria engage in a highly risky business such as foreign exchange trading, oil, and gas business, stock market margin finance as their major source of earnings, especially, when they have high liquidity influx. For instance, Sanusi (2011) states that the abundant liquidity into the banks had led to excessive lending by the Nigerian banks which subsequently resulted to loan growth and loan concentration in the oil and gas business and margin finance. Consequently, the high risk-taking behaviour has led to the taking over of Afribank; Finbank, Intercontinental Bank, Oceanic bank and Union Bank by the Central Bank of Nigeria due to insolvency. Similarly, Skye Bank and Diamond bank have been taken over by the Polaris bank and Access bank, respectively. Scholars such as Acharya and Naqvi (2012), Allen and Gale (2000), Barlevy (2014), and Wagner (2007) documented that large liquidity inflow shield banks from funding liquidity risk and thus, aggravate their risktaking behaviour by high risk in a pursue of short-term returns that will eventually lead to crisis. According to Sanusi (2011), the abundant liquidity that had led to the crisis was emanated from the large amount of deposit inflow from the government large foreign 
exchange earned from the excess crude oil price, and the proceeds of the 2005 consolidation and re-capitalisation exercise. Considering the public loss of confidence as a result of bank distress which has bedevilled the financial sector in the last decades; and the intensity of competition in the banking sector due to the emergence of large number of new banks, every deposit money bank should ensure that it operates on profit and at the same time meets the financial demands of its depositors by maintaining adequate liquidity. The problem then becomes how to select or identify the optimum point or the level at which a deposit money bank can maintain its assets in order to optimize these two objectives since each of the liquidity has a different effect on the level of profitability. This problem becomes more pronounced as good numbers of deposit money banks are engrossed with profit maximization and as such, they tend to neglect the importance of liquidity management. However, the profit maximization becomes a myth as the resulted liquidity can lead to both technical and legal insolvency with the consequence of low patronage, deposit flight, erosion of asset base. Hence, this study seeks to determine the impact of macro-economic behaviour on Deposit Money Bank's liquidity, especially in Nigeria.

\section{Literature Review}

Existing literature suggests that bank liquidity is a function of macroeconomic factors. Bank liquidity has been investigated by studies in the past while taking into account bank specific and macroeconomic variables (Bonfim \& Kim, 2012; Bonner, van Lelyveld, \& Zymek, 2013; Delechat et al., 2012; Eichengreen \& Gupta, 2013).

\subsection{Theoretical Literature Review}

\section{A. Keynesian Liquidity Preference Theory}

In macroeconomic theory, liquidity preference is the demand for money, considered as liquidity. The concept was first developed by John Maynard Keynes in his book The General Theory of Employment, Interest and Money (1936) to explain the determination of the interest rate by the supply and demand for money. The demand for money as an asset was theorized to depend on the interest foregone by not holding bonds (here, the term "bonds" can be understood to also represent stocks and other less liquid assets in general, as well as government bonds). Interest rates, he argues, cannot be a reward for saving as such because, if a person hoards his savings in cash, keeping it under his mattress say, he will receive no interest, although he has nevertheless refrained from consuming all his current income. Instead of a reward for saving, interest, in the Keynesian analysis, is a reward for parting with liquidity. According to Keynes, money is the most liquid asset. Liquidity is an attribute to an asset. The more quickly an asset is converted into money the more liquid it is said to be, Gauti B. Eggertsson (2008). As cited in Dimand, Robert W. (2008). According to Keynes, demand for liquidity is determined by three motives: (i) the transactions motive: people prefer to have the liquidity to assure basic transactions, for their income is not constantly available. The amount of liquidity demanded is determined by the level of income: the higher the income, the more money demanded for carrying 
out increased spending. (ii) The precautionary motive: people prefer to have liquidity in the case of social unexpected problems that need unusual costs. The amount of money demanded for this purpose increases as income increases. (iii) Speculative motive: people retain liquidity to speculate that bond prices will fall. When the interest rate decreases people demand more money to hold until the interest rate increases, which would drive down the price of an existing bond to keep its yield in line with the interest rate. Thus, the lower the interest rate, the more money demanded (and vice versa).

\section{B. Financial Intermediation Theory}

Liquidity creation and delegated monitoring are among the key roles of banks as pointed out by the financial intermediation theory (Berger \& Bouwman, 2009; Diamond, 1984). Berger and Bouwman (2009); Diamond (1984); and Holmstrom and Tirole (1998) explained that banks create liquidity to customers by making available sufficient funds for their withdrawal needs. Also, banks transform risk by extending riskless deposits to finance risky loans while earning returns from the risk transfer functions. Thus, the liquidity provision role of banks required that banks maintain a reasonable amount of liquidity to discharge their obligations promptly. Banks ensure prompt and consistent liquidity creation by hedging against liquidity shortfalls by way of maintaining cash and cash equivalents. Though banks are required to maintain a liquidity buffer to mitigate liquidity risk and to insure against liquidity shocks, it is argued that maintaining high levels of assets liquidity can increase the bank risk. Hong et al. (2014) revealed that systematic liquidity risk was the main cause of bank failures occurring over the 2009 to 2010 period in the aftermath of the 2007-2008 GFC. Liquidity risk could lead to bank failures through systematic and idiosyncratic channels. In addition, Acharya and Naqvi (2012) and Wagner (2007) have shown that short-term liquidity has implications for bank risk-taking and bank stability. On the other hand, the theory of delegated monitoring explained that banks play a role as delegated monitors that invest on behalf of their customers (Diamond, 1984). This role could create an agency problem such as the conflict of interest between the capital providers and the business overseers as explained by agency theory (Jensen \& Mecking, 1976). Mairafi et al. (2018) stated that the banks' incentives for risk-taking stemmed from their role as delegated monitors that invest in financial assets on behalf of their clients. Thus, banks in their desire to improve performance and increase returns would give priority to self-most profiting venture such as issuing out more loans to the disadvantage of their depositors and other stakeholders. In line with this, Acharya and Naqvi (2012) in their model have shown how an agency problem aggravates the banks high risk-taking behaviour. In their model, they elucidated that an agency problem prevails in the bank whenever there is an excessive liquidity which stem from large deposit inflows. Thus, banks allocating more funds to loans to increase performance. Consequently, this could lead to high loan growth and loan concentration. Bacha (1998), Gonzalez-Hermosillo (1999), and Laeven (1999) argued that high loan growth and loan concentration are signs of banks poor diversification strategy and high risk-taking that can expose banks to financial risks such as credit risk and 
liquidity risk. Therefore, the bank risk-taking behaviour is revealed on their asset's portfolio, profitability and eventually led to banks failure.

\subsection{Empirical Literature Review}

The effect of macroeconomic behaviour on deposit money bank's liquidity has generated a large volume of empirical studies by both local and foreign scholars with mixed findings using cross sectional, time series and panel data. Some of these studies are country specific while others are cross country. Few of the empirical studies are selected for reviews are as follows for instance;

\subsubsection{Local Studies}

Somoye and Ilo (2009) investigated the impact of macroeconomic instability on banking sector lending behaviour in Nigeria using data on commercial banks and macroeconomic instability from 1986 to 2005. The study employed a co-integration and VECM framework to show that bank lending has a long-run relationship with macroeconomic instability. Using the money supply, exchange rate of the Naira to the US dollar, and the inflation rate as well as bank specific control variables, the authors set out to explore the dynamics of this relationship for the Nigerian economy. This study showed that while increases in broad money supply and inflation induced banks to curtail lending, exchange rate depreciation induced the industry to increase lending in the long-run. Additionally, the deposit mobilization capacity of banks and bank size were the most important bank characteristics that explained their lending behaviour given the vagaries of the macroeconomic environment.

Bassey et al. (2016) examined the connection between liquidity management and Nigerian banks performance. Test data for ten years (2000-2010) was obtained from secondary data and analysed using simple regression analysis making use of the SPSS software. Empirical evidence indicates that the bank's deposit has a positive effect on reserve requirement, but the bank's deposit has a negative effect on the liquidity management and bank performance. The authors concluded that banks should be able to make use of liquidity tools to ensure their survival and operations, of the company, thereby satisfying the customer.

Kurotamunobaraomi et al. (2017). Empirically investigated the interrelationship between liquidity and corporate performance of banks in Nigeria with the use of annual data from 1984 to 2014. The work utilized Cash Reserve Ratio, Liquidity Ratio and Loanto-Deposit Ratio as proxies for liquidity; and Return on Shareholders' funds as the proxy for performance and applied finometric analyses that include Ordinary Least Square Regression, Johanson Cointegration, Granger Causality test and Error Correction Model. Empirical results indicated a significant negative short-run relationship between Cash Reserve Ratio and corporate performance as well as a positive relationship between Loan-to- Deposit Ratio and Liquidity Ratio on one hand and corporate performance on the other albeit significantly and insignificantly respectively.

Also, in Nigeria, Daniel (2017) surveyed the management of liquidity and its impact on efficiency of banks. The period was total of 25 years (1986-2011). The target 
population was based on 24 banks. Test data for the research was obtained from secondary data and analysed using the SPSS package. The results of this study indicated that liquidity management positively influences the operations of deposit money banks. The researcher also explained the data using correlation analysis and found that equity returns and cash liquidity reserve ratio are positively related, while equity returns and deposit loan ratio are negatively related. He recommends that banks should adopt optimum liquidity strategies for the smooth running of the business.

Ibe (2013) studied liquidity management and bank performance using profit after tax as a proxy for performance. Test data for the study was obtained using secondary data from the Nigeria Stock Exchange and analysed using a regression model, a unit root test. The result shows that cash and short-term fund contributed negatively to the financial performance of two banks and contributed averagely to the performance of the remaining bank. Ibe (2013) opined that performance of banks is considerably influenced by treasury bills as well as certificates and concluded that banks should acquire more of such assets. He recommends that banks should employ qualified and trained personnel for the right decisions to be made to make a profit.

Ndoka, Islami, and Shima (2017) carried out a study on whether liquidity risk management and performance are related. Test data was obtained from secondary data and analysed using E-view package. The performance was measured using profit after tax, while liquidity ratio was measured using cash, deposits, and liquidity. The results showed that there is a positive relationship between profit before tax and cash, while the relationship between deposits and profit before tax is negative.

Osamwonji and Chijuka (2014) investigated the effect of macroeconomic variables on profitability of commercial banks. The study was based on 1990 to 2013 secondary data obtained in Nigeria. The secondary data was obtained from central bank as well as firms annual reports and financials. Macroeconomic variables studied are GDP, inflation rate, and interest rate; the proxy for profitability being return on equity. Data analysis was by 17 way of ordinary regression. The study finds a significant positive relationship between GDP and return on equity, a significant negative relationship between return on equity and interest rate, and an insignificant negative relation involving inflation rate. This study however fails to indicate neither the population of the study nor the sample used.

\subsubsection{Foreign Studies}

Recent study by Bonner et al. (2015) used data from 30 different countries and found that the correlations of bank liquidity buffers (e.g., liquid assets-to-deposits, liquid assets-tototal assets) with deposit liabilities, market concentration, and bank size are substantially weaker in countries with bank liquidity regulations. They concluded that liquidity regulations act as substitutes for (i.e., reduce) active liquidity management of banks. The implication suggests that the liquidity regulations guide the banks' risk-taking behaviour. Thus, it will help to mitigate the excessive risk-taking behaviour of banks particularly, as the liquidity regulation providing a benchmark which a bank should maintain at any particular period. 
Supporting this view, Bonner (2016) examined the effects of regulatory liquidity coverage ratios on 17 banks in the Netherlands, and concluded that liquidity regulation has real effects, causing banks to increase their investments in government bonds and decrease their investments in loans. Umar et al. (2016) in their study distinguished the terms funding liquidity, liquidity creation, and stock liquidity (referred to as bank liquidity) and use NSFR to proxy for funding liquidity and stock liquidity to proxy for stock illiquidity. Using three-stage least square estimations simultaneously and examines a sample of 188 banks operating in Brazil, Russia, India, China and South Africa (BRICS) for the period 2007-2014. Their finding revealed that the liquidity creation has a significant negative effect on funding liquidity.

A study by Dahir et al. (2017) revealed a significant and negative relationship between liquidity risk and the bank risk-taking behaviour. Meanwhile, study by Imbierowicz and Rauch (2014) examined the relationship between the two main factors such as liquidity risk and credit risk that are related to the reasons for the banks existence which are the sources of banks risks. They used data-set of banks from the US during the period 1998-2010 in assessing the relationship between the two main sources of the bank's risks. They concluded that both liquidity risk and credit risk jointly or individually contribute to the bank probability of default despite the fact that they are not contemporaneous. This view is consistent with the finding of Hong et al. (2014) who examined the potential relation and the impact of Basel III liquidity coverage ratio and net stable funding ratio on the bank's failures. Employing data from the US banks for the period 2001 to 2011, they reported that the two ratios potentially have limited impact on the probability of bank failures, but systemic liquidity risk significantly contributes to the bank failures.

Vazquez \& Federico (2015) studied a higher number of sample banks in the US and Europe within the period 2001 to 2009. In addition, they argued that higher funding stability measured by net stable funding ratio reduces the probability of bank failures. However, they further explained that only domestically smaller banks are more exposed to liquidity risk while larger international banks are more exposed to solvency risk because of higher leverage. Talavera et al. (2006) studied the behaviour of bank lending and macroeconomic uncertainty in Ukraine. Using consumer or producer inflation or changes in money supply (M1 and M2) and its component (demand and time deposit) as proxy for macroeconomic uncertainty, they found a negative relationship between bank loan to capital ratio and macroeconomic uncertainty. The result also reveals that banks increased their lending ratios when macroeconomic uncertainty decreases. However, the study found that the reaction of banks to changes in uncertainty is not uniform and depends on bank-specific characteristics, in particular, bank size and profitability. Zhang and Daly (2013) examined how macroeconomic and bank specific factors affect the performance of banks in China. The study period covered was 2004 to 2010. The population of the study comprised all the banks in China; a sample of 124 banks with complete data set was studied. Secondary data was collected and used by the study. Return on assets was used as a proxy for profitability. Data collected was analysed using regression analysis. The research study indicates that banks with lower credit risk, and 
well capitalized are more profitable; banks with higher expense preference exert negative effect on performance. Banks also grow along with growth in the economy; greater economic amalgamation increases bank profitability.

San and Heng (2013) investigated how macroeconomic conditions and bank specific characteristics affect the performance of Malaysian commercial banks. Period of study covered 2003 to 2009 . Secondary data in this study was obtained and used by the study. 23 banks comprised the population; 20 banks were sampled (three banks had missing data, thus excluded). Data analysis was made via regression analysis and descriptive statistics. The study finds that return on assets ratio is the best measure for profitability. Macroeconomic variables such as gross domestic growth and inflation are found not affecting profitability. Bank specific determinants however affect bank performance.

Kanwal and Nadeem (2013) also in a research study sought to establish the relationship that exists between macroeconomic variables (GDP, inflation rate, interest rate) and profitability (measured by return on assets, return on equity, and equity multiplier) of public commercial banks in Pakistan. The study covered a period 2001-2011 (ten years). Population comprised thirty-eight banks; a sample of twenty-three listed banks was studied. Data was sourced from secondary sources and analysed using correlation analysis, descriptive statistics as well as pooled ordinary least squares regression analysis. The researchers find a strong positive relationship between profitability and interest rate, an insignificant positive relationship between GDP and profitability and a weak negative relationship between inflation rate and bank profitability. In summary the study concludes that there exists a weak relationship between macroeconomic variables and commercial banks earnings.

Irina Bunda, and Jean-Baptiste Desquilbet, (2003) examined the relationship between Bank Liquidity and Exchange Rate Regimes collecting sample of commercial banks in emerging countries between 1995 and 2000. The result showed that there exists a "bank liquidity smile across exchange rate regimes".

Gerlach, Peng and Shu (2005) undertook a study to investigate how macroeconomic development affects the profitability of banks. The study was undertaken in Hong Kong and covered the period 1994 to 2002. Population studied consisted of twenty-nine retail banks in Hong Kong; the study was a census study. Secondary data was obtained and analysed using regression analysis. The study finds macroeconomic changes to influence business cycles and changes and affects bank profitability in a significant manner. The study used net interest margin and nonperforming loans (ratio of these loans to total loans and advances) as the proxy for bank profitability.

\section{Material and Methodology}

\subsection{Sources of Data}

In other to determine the impact of macroeconomic behaviour on deposit money bank liquidity in Nigeria, the study decides to employ correlation matrix, variance inflation 
factor and autoregressive distributed lag to analyse how the dependent variable responds to independent variables. Annual time-series data on Liquidity ratio (LQR) which is used as a proxy for deposit money bank's liquidity are drawn from Central Bank of Nigeria for the periods of 1990 to 2020 and it is in percentage. Whilst, annual time-series data on Credit to Private Sector (CPS) and Money Supply (M2) are sourced from Central Bank of Nigeria and National Bureau of Statistics for the periods of 1990 to 2020 and are Billions of Naira respectively. Also, annual time-series data on real interest rate (R_INTR) which are in percentage and exchange rate (EXCHR) which are in units are both taken from World Development Indicators for the periods of 1990 and 2020 respectively.

\subsection{Model Specification}

This study is anchored on the theory of liquidity preference modelled by Keynes (1936), for the theory; liquidity preference is the demand for money, which is considered as liquidity. The theory explains that the determination of the interest rate by the supply and demand for money. The demand for money as an asset was theorized to depend on the interest foregone by not holding bonds (here, the term "bonds" can be understood to also represent stocks and other less liquid assets in general, as well as government bonds). Interest rates, he argues, cannot be a reward for saving as such because, if a person hoards his savings in cash, keeping it under his mattress say, he will receive no interest, although he has nevertheless refrained from consuming all his current income. Instead of a reward for saving, interest, in the Keynesian analysis, is a reward for parting with liquidity. According to Keynes, money is the most liquid asset. Liquidity is an attribute to an asset. The more quickly an asset is converted into money the more liquid it is said to be. In the light of this theory, the model which is used to investigating macroeconomic behaviour and deposit money bank's liquidity in Nigeria is based on that proposed by Osamwonji and Chijuka (2014) with modification. The authors proposed that profitability of commercial banks which was proxied for return on equity was affected by some macroeconomic variables; such as interest rate, GDP, inflation rate. In this study, the model is modified to include money supply (M2), Credit to private sector (CPS), Exchange rate (EXCHR), and liquidity ratio (LQR) which is used as a proxy for deposit money bank's liquidity. These variables may significantly influence liquidity ratio as veritable instruments of macroeconomic behaviour. Besides, the DMB's liquidity is absorbed while each macroeconomic instrument is split to enable us examine its significant impact on the liquidity ratio. Based on this relationship, a functional form of the impact of macroeconomic behaviour on deposit money bank liquidity in Nigeria is illustrated as:

$\mathrm{LQR}=\mathrm{f}\left(\mathrm{M} 2, \mathrm{EXCHR}, \mathrm{CPS}, \mathrm{R} \_\right.$INTR $)$

Where;

LQR = Liquidity Ratio (Dependent Variable)

M2 = Money supply (Explanatory Variable)

$\mathrm{EXCHR}=$ Exchange rate (Explanatory variable) 
$\mathrm{CPS}=$ Credit to private sector (Explanatory Variable)

R_INTR $=$ Real Interest rate (Explanatory Variable)

The equation above can be expressed as follows:

$\mathrm{LQR}=\beta_{0}+\beta_{1} \mathrm{M} 2+\beta_{2} \mathrm{EXCHR}+\beta_{3} \mathrm{CPS}+\beta_{4} \mathrm{R} \_\mathrm{INTR}+\mu$

Where:

$\beta_{0}=$ Constant term,

$\beta_{1}=$ Parameter coefficient of M2;

$\beta_{2}=$ Parameter coefficient of EXCHR;

$\beta_{3}=$ Parameter coefficient of CPS;

$\beta_{4}=$ Parameter coefficient of R_INTR;

$\mu \mathrm{t}=$ Error Term.

To investigate the long-run and short-run relationships among the study variables, the study utilises Autoregressive Distributive Lag (ARDL) technique. The model is expressed hereunder as follows;

$\Delta \mathrm{LOGLQR}_{\mathrm{t}-1}=\beta_{0}+\sum_{t-1}^{M} \beta 1 \Delta \mathrm{LOGLQR}_{\mathrm{t}-1}+\sum_{t-1}^{N} \beta 2 \Delta \mathrm{LOGM}_{\mathrm{t}-1}+\sum_{t-1}^{P} \beta 3 \Delta$ LOGOEXCHR $_{\mathrm{t}-1}+$ $\sum_{t-1}^{Q} \beta 4 \Delta$ LOGCPS $_{\mathrm{t}-1}+\sum_{t-1}^{R} \beta 5 \Delta$ LOGLR_INTR $-1_{\mathrm{t}}+\delta_{1}$ LOGLQR $_{\mathrm{t}-1}+\delta_{2}$ LOGM $_{\mathrm{t}-1}+$ $\delta_{3} \mathrm{LOGOEXCHR}_{\mathrm{t}-1}+\delta_{4} \mathrm{LOGCPS}_{\mathrm{t}-1}+\delta_{5} \mathrm{LOGR}_{-} \mathrm{INTR}_{\mathrm{t}-1}+\varepsilon_{\mathrm{it}}$

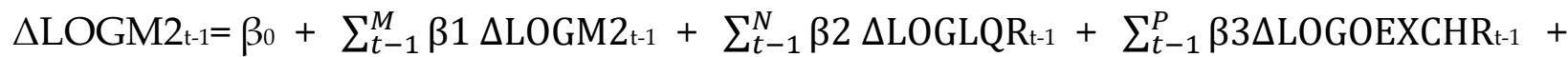
$\sum_{t-1}^{Q} \beta 4 \Delta$ LOGCPS $_{\mathrm{t}-1}+\sum_{t-1}^{R} \beta 5 \Delta$ LOGLR_INTR $-1_{\mathrm{t}}+\delta_{1}$ LOGM2 $_{\mathrm{t}-1}+\delta_{2}$ LOGLQR $_{\mathrm{t}-1}+$ $\delta_{3} \mathrm{LOGOEXCHR}_{\mathrm{t}-1}+\delta_{4} \mathrm{LOGCPS}_{\mathrm{t}-1}+\delta_{5} \mathrm{LOGR}_{-} \mathrm{INTR}_{\mathrm{t}-1}+\varepsilon_{\mathrm{it}}$

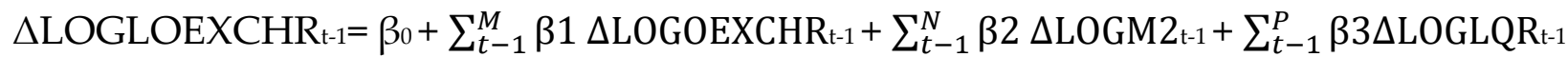
$+\sum_{t-1}^{Q} \beta 4 \Delta$ LOGCPS $_{\mathrm{t}-1}+\sum_{t-1}^{R} \beta 5 \Delta$ LOGLR_INTR $_{\mathrm{t}-1}+\delta_{1}$ LOGLOEXCHR $_{\mathrm{t}-1}+\delta_{2}$ LOGM2 $_{\mathrm{t}-1}+$ $\delta_{3}$ LOGLQR $_{\mathrm{t}-1} \quad+\quad \delta_{4}$ LOGCPS $_{\mathrm{t}-1}+\delta_{5}$ LOGR_INTR $_{\mathrm{t}-1}+\varepsilon_{\text {it }}$

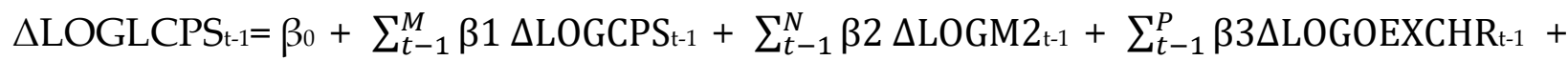
$\sum_{t-1}^{Q} \beta 4 \Delta$ LOGLQR $-1_{t}+\sum_{t-1}^{R} \beta 5 \Delta$ LOGLR_INTRt $1_{-}+\delta_{1}$ LOGCPS $-1_{\mathrm{t}}+\delta_{2}$ LOGM $_{\mathrm{t}-1}+$ $\delta_{3} \mathrm{LOGOEXCHR}_{\mathrm{t}-1}+\delta_{4} \mathrm{LOGLQR}_{\mathrm{t}-1}+\delta_{5} \mathrm{LOGR} \_$INTR $\mathrm{t}-1+\varepsilon_{\text {it }}$

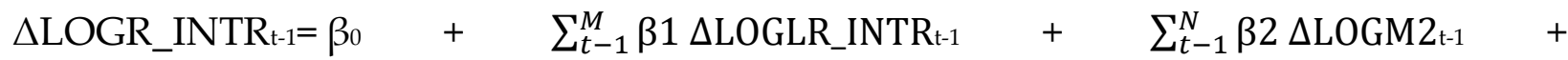
$\sum_{t-1}^{P} \beta 3 \Delta$ LOGOEXCHR $_{\mathrm{t}-1}+\sum_{t-1}^{Q} \beta 4 \Delta$ LOGCPS $_{\mathrm{t}-1}+\sum_{t-1}^{R} \beta 5 \Delta$ LOGLQR $\mathrm{t}-1+\delta_{1}$ LOGR_INTR $_{\mathrm{t}-1}+$ $\delta_{2} \mathrm{LOGM}_{\mathrm{t}-1}+\delta_{3} \mathrm{LOGOEXCHR}_{\mathrm{t}-1}+\delta_{4} \mathrm{LOGCPS}_{\mathrm{t}-1}+\delta_{5} \mathrm{LOGLQR}_{\mathrm{t}-1}+\varepsilon_{\mathrm{it}}$

Where:

$\Delta$ stands for the first difference operator

$\beta_{0}$ stands for constant term 
$\beta_{1}-\beta_{5}$ stand for short-run elasticity (Coefficients of the first-differenced explanatory variables)

$\delta_{1}-\delta_{5}$ stand for long-run elasticity (coefficients of the explanatory variables)

$i=1 \ldots \mathrm{M} ; \mathrm{N}, \mathrm{P}, \mathrm{Q}, \mathrm{R}$, are optimal lag orders

$\varepsilon_{\text {it }}$ stands for vector of the error terms - unobservable zero mean white noise vector process (serially uncorrelated or independent).

\subsection{A priori expectations}

In accordance with economic theory, it is expected that $\beta_{2}$, and $\beta_{4}$, are expected to be positive, that is $>0 . \beta_{1}$ and $\beta_{3}$ are expected to be negative, that is $<0$.

\section{Results and Discussion}

\subsection{Correlation Matrix analysis}

This section reports correlations between explanatory variables and the Variance Inflation Factor (VIF) results are presented in table $4 \mathrm{a}$ and table $4 \mathrm{~b}$ under here, this study as part of its preliminary analysis attempt to test for the level of linear dependency among the explanatory variables of the study using the Pearson correlation and the Variance Inflation Factor methods. The Pearson's correlation test finds no significant evidence of any strong multicollinearity problem. Absence of multicollinearity problem was further confirmed by value of VIF test for multicollinearity, which is below 10 the conventional threshold size.

Table 4a: Correlation Matrix Statistic Results

\begin{tabular}{|l|c|c|c|c|c|}
\hline Variables & LQR & M2 & CPS & EXCHR & R_INTR \\
\hline LQR & 1.000000 & 0.45630 & -0.026379 & 0.447823 & 0.029881 \\
\hline M2 & 0.45630 & 1.000000 & & & \\
\hline CPS & -0.026379 & & 1.000000 & & \\
\hline EXCHR & 0.447823 & & & 1.000000 & \\
\hline R_INTR & 0.029881 & & & & 1.000000 \\
\hline
\end{tabular}

Source: Authors' computation with E-view 10 Software.

Table 4b: Variance Inflation Factor

\begin{tabular}{|l|c|c|c|}
\hline Variables & Coefficient Variance & Uncentered VIF & Centered VIF \\
\hline C & 612.4218 & 9.896756 & N/A \\
\hline M2 & $1.99 \mathrm{E}-24$ & 6.0943889 & 3.939690 \\
\hline EXCHR & 0.037598 & 13.61627 & 4.626743 \\
\hline CPS & 6.911030 & 13.25990 & 1.557456 \\
\hline R_INTR & 0.703776 & 1.353562 & 1.242308 \\
\hline
\end{tabular}

Source: Authors' computation with E-view 10 Software.

The correlation matrix is to check for multicollinearity and to explore the association between each explanatory variable and the dependent variable. The findings from the correlation matrix table (table 4 a above) show that Liquidity ratio (LQR) portrays a weak positive association with money supply (M2), exchange rate (EXCHR), and real interest 
rate (R_INTR) with associated value of $0.45630,0.447823$ and 0.029881 respectively; meaning that as the values of money supply, exchange rate and real interest rate increase in the economy the value of liquidity ratio would tend to positively increase ceteris paribus. Conversely, it is revealed from the result that Liquidity ratio (LQR) indicates a weak negative association with credit to private (CPS) with an associated value of 0.026379; meaning that as banks attempt to increase credit to private sector on the average the value of liquidity ratio would tend to decrease. In confirming the correlation analysis results, a test of Variance Inflation Factor is carried out, the result report from Centered VIF indicates that all the independent variables are free from multicollinearity as their values fall between 1 and 5 which is far more below the thresholds of 10 , meaning that they are moderately correlated.

\subsection{Stationarity Test for Study Variables}

Before carrying out the ARDL co-integration exercise, the study first and foremost conducts test for the order of integration of the variables to ensure that none of the study variables is stationary at second differencing, since the ARDL bounds test fails to provide robust results in the presence of $\mathrm{I}(2)$ variables. The study thus, applies two types of widely recognised unit root tests of Augmented Dickey-Fuller (Dickey \& Fuller, 1976) test and Philips-Peron (1988) test to check for the stationarity properties of the study variables to guard against spurious regression. These tests are both conducted at levels I(0) and first difference I(1). The results of the unit root tests are presented in Table 4c below.

Table 4c: Unit Roots Test Results

\begin{tabular}{|l|c|c|c|c|c|c|c|c|}
\hline Series & $\begin{array}{c}\text { ADFT } \\
\text { Level }\end{array}$ & $\begin{array}{c}\text { Critical } \\
\text { Level }\end{array}$ & $\begin{array}{c}\text { Order of } \\
\text { INTN }\end{array}$ & $\begin{array}{c}\text { P- } \\
\text { VALUE }\end{array}$ & PPT & $\begin{array}{c}\text { Critical } \\
\text { Level }\end{array}$ & $\begin{array}{c}\text { Order of } \\
\text { INTN }\end{array}$ & P-Value \\
\hline LOG(LQR) & -0.674571 & -2.963972 & $\mathrm{I}(0)$ & 0.8383 & -0.674571 & -2.963972 & $\mathrm{I}(0)$ & 0.8383 \\
D(LOG(LQR)) & -5.625449 & -2.967767 & $\mathrm{I}(1)$ & 0.0001 & -5.628187 & -2.967767 & $\mathrm{I}(1)$ & 0.0001 \\
\hline LOG(M2)) & -0.961173 & -2.976263 & $\mathrm{I}(0)$ & 0.7522 & -3.712938 & -2.967767 & $\mathrm{I}(0)$ & 0.0092 \\
D(LOG(M2)) & -10.06043 & -2.976263 & $\mathrm{I}(1)$ & 0.0000 & & & & \\
\hline (LOG(EXCHR)) & -1.879666 & -2.963972 & $\mathrm{I}(0)$ & 0.3369 & -1.972961 & -2.963972 & $\mathrm{I}(0)$ & 0.2965 \\
D(LOG(EXCHR)) & -5.059218 & 2.967767 & $\mathrm{I}(1)$ & 0.0003 & -5.059826 & -2.967767 & $\mathrm{I}(1)$ & 0.0003 \\
\hline (LOG(CPS)) & -2.290081 & -2.963972 & $\mathrm{I}(0)$ & 0.1815 & -2.184951 & -2.963972 & $\mathrm{I}(0)$ & 0.2155 \\
D(LOG(CPS)) & -4.416529 & -2.976263 & $\mathrm{I}(1)$ & 0.0018 & -7.144946 & -2.967767 & $\mathrm{I}(1)$ & 0.0000 \\
\hline R_INTR & -3.277390 & -2.963972 & $\mathrm{I}(0)$ & 0.0251 & -3.277390 & -2.963972 & $\mathrm{I}(0)$ & 0.0251 \\
\hline
\end{tabular}

Source: Authors' Computation with E-view 10 (Based on AIC, MaxLag 2) At 5\%.

From the results in Table 4c, the study can correctly conclude that none of the variables in our study is integrated of order two I(2). However, the variables in our model have a mixed order of integration including the dependent variable (LQR) in both tests which fulfil the requirements for using the ARDL estimation method for our empirical analysis. After being satisfied with the necessary and sufficient conditions for using the ARDL estimation technique, we are therefore certain that the co-integration analysis using this technique will generate valid and/or reliable regression results.

\subsection{ARDL Bounds Test of Co-integration}

The bounds test procedure is based on the F-test for determining the presence of longrun linkage between the study variables and it tests for the joint significance of lagged 
level variables involved in the model. For the F-test, the selection of maximum lag length is very important. The observations in the study are annual and sample size is 31 with 4 parameters. For such a small sample size as suggested by Pesaran et al. (2001), the study adopts automatic selected-maximum lag length of 4 . The estimated bounds and F-test results are displayed in Table $4 \mathrm{~d}$.

Table 4d: ARDL bounds test of co-integration results

\begin{tabular}{|l|c|c|c|c|l|}
\hline F- Bounds Test & & & \multicolumn{3}{|c|}{ Null Hypothesis No levels relationship } \\
\cline { 1 - 4 } Test Statistic & Value & Signif. & $\begin{array}{c}\text { Low Bounds } \\
\text { I(0) }\end{array}$ & $\begin{array}{c}\text { Upper Bounds } \\
\text { I(1) }\end{array}$ & Decision \\
\hline F- Statistic & 10.66718 & $10 \%$ & 2.45 & 3.52 & Reject H0: and Accept H1: \\
\cline { 1 - 2 } & 4 & $5 \%$ & 2.86 & 4.01 & Co-integration Exists \\
\hline & & $2.5 \%$ & 3.25 & 4.49 & \\
\hline & & $1 \%$ & 3.74 & 5.06 & \\
\hline
\end{tabular}

Source: Authors' Computation with E-view 10 Software.

The bounds testing results indicate that the null hypothesis is rejected at $5 \%$ level of significance as there is evidence of cointegrating relationship in the model which is motivated by the explanatory variables (M2, EXCHR, CPS, R_INTR). This implies liquidity ratio (LQR), Money supply (M2), exchange rate (EXCHR), Credit to private sector (CPS), and Real interest rate (R_INTR) are bound by a long-run relationship. The long-run relationship among the variables is confirmed as the calculated F-ratio (LQR, M2, EXCHR, CPS, R_INTR,) $=10.66718$ which happens to be greater than the upper bound I(1) critical value of 4.01 and lower bound I(0) critical value of 2.86 at the $5 \%$ level of significance, respectively. The implication of this co-integrating relationship is that Liquidity ratio trails changes in selected macroeconomic variables over a long period. Hence, it is concluded that M2, EXCHR, CPS, R_INTR collectively explain variations in LQR.

\subsection{Long-run Impact of Macro-economic Behaviour on Liquidity Ratio in Nigeria}

After ascertaining the co-integration relationship, the study proceeds with the estimation of long-run dynamics using the conditional long-run autoregressive distributed lag (ARDL) model to determine the long-run effect of macro-economic behaviour on deposit money bank liquidity ratio in Nigeria for equation 3. The study utilizes the Akaike Information Criteria (AIC) to guide the choice of the lag length, selecting 4 as the maximum number of lags for both the explained and the explanatory variables. The longand short-run coefficients from equation 3 are hence estimated using an optimally determined lag length of $(4,4,3,4,3)$ and the results are presented in Table $4 \mathrm{e}$. 
Table 4e: ARDL Long-run estimated results

\begin{tabular}{|l|c|c|c|c|}
\hline Variables & Coefficient & Std. Error & t-Statistic & Prob. \\
\hline C & 4.911927 & 7.526049 & 0.652657 & 0.5605 \\
\hline LOG(LQR(-1))* & -3.174671 & 1.555963 & -2.040325 & 0.1340 \\
\hline LOG(M2(-1)) & -0.186677 & 0.183336 & -1.018226 & 0.3835 \\
\hline LOG(EXCHR(-1)) & 3.340284 & 1.094151 & 3.052853 & 0.0553 \\
\hline LOG(CPS(-1)) & -1.124789 & 1.308564 & -0.859560 & 0.4532 \\
\hline R_INTR(-1)) & -0.293667 & 0.063524 & -4.622933 & 0.0191 \\
\hline DLOG(LQR(-1)) & -2.299346 & 0.906716 & -2.535905 & 0.0850 \\
\hline DLOG(LQR(-2)) & -0.279526 & 0.8858349 & -0.325655 & 0.7661 \\
\hline DLOG(LQR(-3)) & 0.324424 & 0.543602 & 0.596804 & 0.5927 \\
\hline DLOG(M2) & -0.134404 & 0.045490 & -2.954604 & 0.0598 \\
\hline DLOG(M2(-1)) & 0.029301 & 0.164849 & 0.177744 & 0.8702 \\
\hline DLOG(M2(-2)) & 0.022774 & 0.094935 & 0.239894 & 0.8259 \\
\hline DLOG(M2(-3)) & -0.061716 & 0.044095 & -1.399619 & 0.2561 \\
\hline DLOG(EXCHR) & 4.047529 & 0.983109 & 4.117068 & 0.0260 \\
\hline DLOG(EXCHR(-1)) & 2.532960 & 0.455979 & 5.554996 & 0.0115 \\
\hline DLOG(EXCHR(-2)) & 2.101070 & 0.404086 & 5.199560 & 0.0138 \\
\hline DLOG(CPS) & 2.313637 & 0.614759 & 3.763488 & 0.0328 \\
\hline DLOG(CPS(-1)) & -2.804539 & 0.989152 & -2.835298 & 0.0659 \\
\hline DLOG(CPS(-2)) & -1.491331 & 1.089110 & -1.369311 & 0.2644 \\
\hline DLOG(CPS(-3)) & -1.468339 & 0.805276 & -1.823398 & 0.1658 \\
\hline D(R_INTR) & -0.108496 & 0.019274 & -5.629227 & 0.0111 \\
\hline D(R_INTR(-1)) & 0.226181 & 0.051982 & 4.351112 & 0.0224 \\
\hline D(R_INTR(-2)) & 0.123864 & 0.028510 & 4.344618 & 0.0225 \\
\hline Source:Autors' Com & & & \\
\hline
\end{tabular}

Source: Authors' Computation with E-view 10 Software.

From the long-run ARDL results above, The coefficient (-3.174671) and its corresponding P-value being (0.1340) of LQR(-1) portrays that the observed value of liquidity ratio of the previous year has negative and insignificant impact on current year's liquidity ratio. It is revealed that the long-run absolute value of the coefficient of money supply (M2) depicts a negative relationship with liquidity ratio (LQR) that is insignificant at $5 \%$ level, it implies that a percentage increase in the amount of money supply (M2), ceteris paribus, is connected with about $13.44 \%$ decline in liquidity ratio (LQR). The negative sign of this variable is consistent with a-priori expectation which suggests their inverse relationship that as money supply increases there would be a corresponding decline in the liquidity ratio in the long-run. Empirical study by Talavera et al. (2006) who investigated the behaviour of bank lending and macroeconomic uncertainty in Ukraine found similar result. More so, the long-run absolute value of the coefficient of exchange rate (EXCHR) indicate a positive impact on liquidity ratio that is significant at $5 \%$ level, this implies that a percentage increase in exchange rate holding other predictor variables constant triggers about $4.04 \%$ increase in long-term liquidity ratio. The result also conforms to a priori expectation suggesting their positive relationship that as exchange rate increases that will lead to increase in deposit money bank liquidity as measured by liquidity ratio. And also, it is in line with the finding of Irina Bunda, Jean-Baptiste Desquilbet, (2003). Who examined the relationship between Bank Liquidity and Exchange Rate Regimes collecting sample of commercial banks in emerging countries between 1995 and 2000, and 
found that there exists a "bank liquidity smile across exchange rate regimes. The absolute value of the long-run coefficient of credit to private sector is positive and its corresponding p-value is significant at $5 \%$ level. Hence, the result is not consistent with a-priori expectation. Based on this result, a percentage point increase in credit to private sector is expected to increase liquidity ratio by approximately $2.31 \%$ ceteris paribus. The result is not in conformity with the Basel Accord of liquidity ratio which requires banks to hold more cash and might lead to fewer loans issued to consumers and business. Furthermore, the absolute value of the long-run coefficient of real interest rate (R_INTR) is negative and its corresponding $\mathrm{p}$-value is significant at $5 \%$ level. Hence, a percentage increase in real interest rate, other things being equal, inflict a significant decrease of about $10.84 \%$ in long-term of liquidity ratio. This is in line with economic theory which suggests that when interest rates are low, demand for cash is high and stakeholders may prefer to hold assets until interest rates rise. On the other hand, when interest rates are offered, investors give up liquidity in exchange for higher rates.

\subsection{Short-run Impact of Macro-economic Behaviour on Liquidity Ratio in Nigeria}

The error correction mechanism (ECM) gives information on the speed of adjustments and short-run coefficients of the ARDL model, while the differenced coefficients of the explanatory variables show the short-run dynamics. Specifically, the ECM estimation provides information on the speed at which liquidity ratio returns to equilibrium after a shock to the explanatory variables (Money supply, exchange rate, credit to private sector and real interest rate). Table $4 \mathrm{f}$ below presents the results of short-run coefficients of the impact of macro-economic behaviour on deposit money bank liquidity ratio in Nigeria.

Table 4f: Short-run estimated ARDL results

\begin{tabular}{|l|c|c|c|c|}
\hline Variable & Coefficient & Std.Error & t-Statistic & Prob. \\
\hline C & 4.911927 & 0.437109 & 11.23730 & 0.0015 \\
\hline DLOG(LQR(-1)) & -2.299346 & 0.247881 & -9.276012 & 0.0027 \\
\hline DLOG(LQR(-2)) & -0.279526 & 0.239983 & -1.164774 & 0.3283 \\
\hline DLOG(LQR(-3)) & 0.324424 & 0.177015 & 1.832742 & 0.1642 \\
\hline DLOG(M2) & -0.134404 & 0.021061 & -6.381528 & 0.0078 \\
\hline DLOG(M2(-1)) & 0.029301 & 0.026385 & 1.110521 & 0.3478 \\
\hline DLOG(M2(-2)) & 0.022774 & 0.024045 & 0.947173 & 0.4134 \\
\hline DLOG(M2(-3)) & -0.061716 & 0.018279 & -3.376433 & 0.0432 \\
\hline DLOG(EXCHR) & 4.047529 & 0.350610 & 11.54424 & 0.0014 \\
\hline DLOG(EXCHR(-1)) & 2.532960 & 0.238364 & 10.62645 & 0.0018 \\
\hline DLOG(EXCHR(-2)) & 2.101070 & 0.222413 & 9.446684 & 0.0025 \\
\hline DLOG(CPS) & 2.313637 & 0.287922 & 8.035644 & 0.0040 \\
\hline DLOG(CPS(-1)) & -2.804539 & 0.261874 & -10.70951 & 0.0017 \\
\hline DLOG(CPS(-2)) & -1.491331 & 0.282385 & -5.281200 & 0.0132 \\
\hline DLOG(CPS(-3)) & -1.468339 & 0.241489 & -6.080356 & 0.0089 \\
\hline D(R_INTR) & -0.108496 & 0.009719 & -11.16350 & 0.0015 \\
\hline D(R_INTR(-1)) & 0.226181 & 0.019422 & 11.64567 & 0.0014 \\
\hline D(R_INTR(-2)) & 0.123864 & 0.011713 & 10.57525 & 0.0018 \\
\hline ECM(-1) & -3.174671 & 0.284577 & -11.15574 & 0.0015 \\
\hline
\end{tabular}

Source: Authors' Computation with E-view 10 Software. 
The ECM shows the speed of adjustment mechanism towards restoring equilibrium following a shock in the long-run. The observed coefficient of the error correction model (ECM) is found to be negative (-3.174671) and statistically significant (0.0015). A negative and statistically significant ECM portrays how rapidly liquidity ratio return to equilibrium after a shock or disturbance to macro-economic behaviour in the long-run. In absolute term, the relatively high adjustment mechanism denoted by the coefficient $3.174671(3.17 \%)$ associated with the ECM implies a rapid adjustment process in the model. This shows that in the current year, approximately $3.17 \%$ of previous year's disequilibrium or shocks adjusted back to long-run equilibrium. The ECM further indicates the presence of a long-run relationship between components of macroeconomic behaviour and liquidity ratio in Nigeria.

Table $4 \mathrm{f}$, shows a percentage increase in one-year lag value of $\mathrm{D}(\mathrm{LQR}(-1))$ is associated with a negative and significant impact of decreasing the current year value of liquidity ratio (LQR) by $2.29 \%$ in both long-run and short-run at $5 \%$ significant level. Similarly, a percentage increase in two years lagged-value of liquidity ratio $(\mathrm{D}(\mathrm{LQR}(-2))$ is related with the negative and insignificant impact of delaying the current level of liquidity ratio by $27.92 \%$ in both long-run and short-run. In the same vein, a percentage increase in three years lagged-value of liquidity ratio $(\mathrm{D}(\mathrm{LQR}(-3))$ enthuses the current level of liquidity ratio in both log-run and short-run by approximately $32.44 \%$. The absolute value of coefficient of present level of money supply DLOG(M2) in connection with the long-run results which displays a negative sign but significantly statistical relationship with the current rate of liquidity ratio at $5 \%$ level. Thus, a percentage increase in the present level of money supply, holding other predictor variables constant, inspires a decrease in current level of LQR by approximately $13.44 \%$. However, the absolute value of the coefficient of the short-run one-year lag and two year lagged-measure of money supply (LOGM2(-1)) and (LOGM2(-2)) in agreement with the long-run result indicates a positive impact on the current rate of liquidity ratio that is insignificant at $5 \%$ level, implying that a percentage increase in one-year lag and two-year lag of money supply would approximately cause about $2.93 \%$ and $2.27 \%$ respective increase in liquidity ratio. Similarly, the absolute value of the coefficient of the three-year-lagged-measure of money supply (LOGM2(-3)) in agreement with the long-run result indicating a negative impact on the current rate of liquidity ratio that is insignificant at $5 \%$ level. In conformity with the long-run results, displaying that a percentage increase in current level of money supply, holding other control variables constant, motivates about $6.17 \%$ decrease in current rate of liquidity ratio. More so, the absolute value of the estimated coefficient of present level of exchange rate $\mathrm{D}(\mathrm{LOGOEXCHR})$ in agreement with the long-run results is positively related to the current rate of liquidity ratio and significant at $5 \%$ level. Based on this result, a percentage increase in the present level of exchange rate, holding other regressors constant, inspires a rise in current level of LQR by approximately $4.04 \%$. However, the absolute value of the coefficient of one-year-lagged-measure and two-yearlagged-measure of exchange rate (LOGOEXCHR(-1)) and LOGOEXCHR(-2)) in agreement with the long-run result shows a positively significant impact on the current rate of liquidity ratio by $2.53 \%$ and $2.10 \%$ respectively. Furthermore, the absolute value 
of the estimated coefficient of the present level of credit to private sector D(LOGCPS) is also in agreement with the long-run result, suggesting that a percentage increase in the present level of credit to private sector will, other things remaining equal, produce a significant increase of about $2.31 \%$ in the current rate of liquidity ratio. In tandem with the long-run result however, the one-year lag, two-year lag and three-year lag of credit to private sector D(LOGCPS(-1)), D(LOGCPS(-2)), and D(LOGCPS(-3)) demonstrate a negative and insignificant impact of $2,80 \%, 1.49 \%$ and $1.46 \%$ on current level of liquidity ratio in the long-run, whereas, in the short-run it is negatively significance. In uniformity with the long-run results, the present level of real interest rate, $D\left(R \_I N T R\right)$, is associated with a negative impact on current rate of liquidity ratio that is significant at $5 \%$ level, indicating that a percentage increase in current level of real interest rate, holding other predictor variables constant, propel about $10.84 \%$ decrease in current rate of liquidity ratio. The one-year lagged-value and two-year lagged-value interest rate D(R_INTR $(-1))$ and $\mathrm{D}\left(\mathrm{R} \_\mathrm{INTR}(-2)\right)$ show the positive and significant impact of increasing interest rate on the current rate of liquidity ratio at $5 \%$ level by $22.61 \%$ and $12.38 \%$ respectively.

\section{Diagnostic Tests}

To carry out analysis that is associated with the reliability and robustness of the ARDL model. For this reason, diverse econometric diagnostic tests are performed to ascertain that economic health of our model is in good condition and free from idiosyncratic shocks. These diagnostic tests include serial correlation, heteroscedasticity, Ramsey's RESET test as well as Jarque-Bera normality test. The results are reported in Table-5 indicate that the ARDL is free from challenges of misspecification, heteroscedasticity, higher-order autocorrelation, or Non-Normality. This implies that the results from the ARDL estimation are robust and reliable for making inferences. Also, the plot of the CUSUM and CUSUM Squares show that the model is stable as the graphs lie within the $5 \%$ significance level boundaries see Figures $5 a$ \& $5 b$

Table 5: Residual Diagnostic Tests

\begin{tabular}{|l|c|c|c|}
\hline Test & Null Hypothesis & F-statistic & P-Value \\
\hline Jarque-Bera & Normally distributed & 4.730330 & 0.093934 \\
\hline Breusch Godfrey & No Serial correlation & 26.01495 & 0.1373 \\
\hline Breusch-Pagan Godfrey & No Heteroscedasticity & 0.223534 & 0.9865 \\
\hline Ramsey Reset & No Misspecification & 4.296629 & 0.3229 \\
\hline
\end{tabular}

Source: Authors' computation with E-view 10 Software. 
Figure-5a: Plot of CUSUM test for model stability at 5\% level of significance

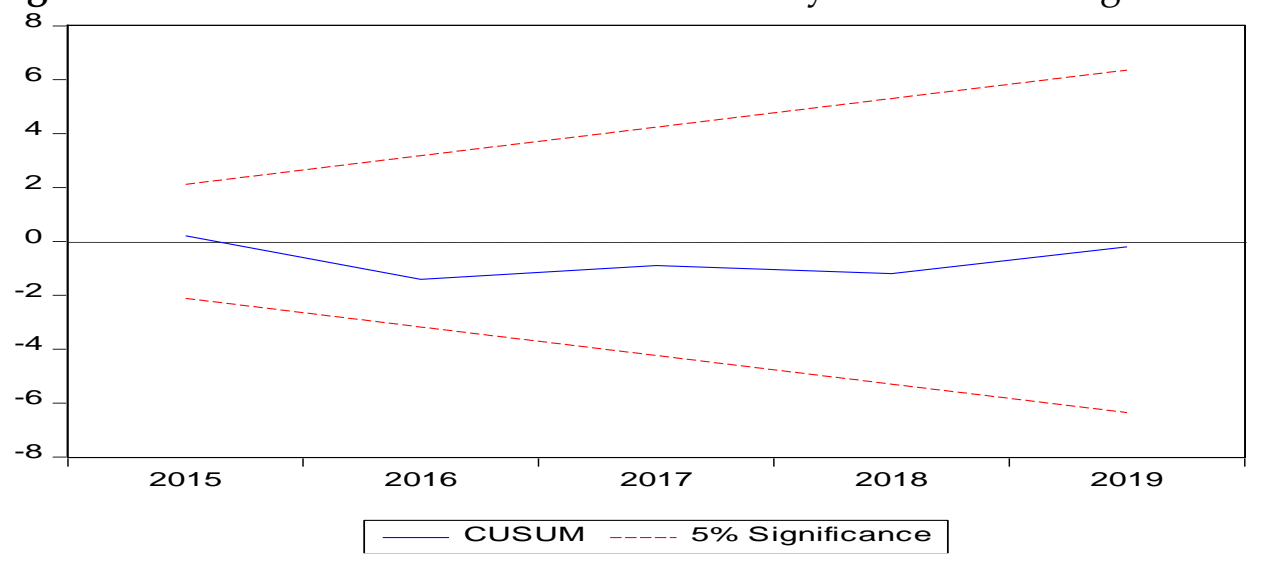

Figure-5b: Plot of CUSUM of Square test for model stability at 5\% level of significance

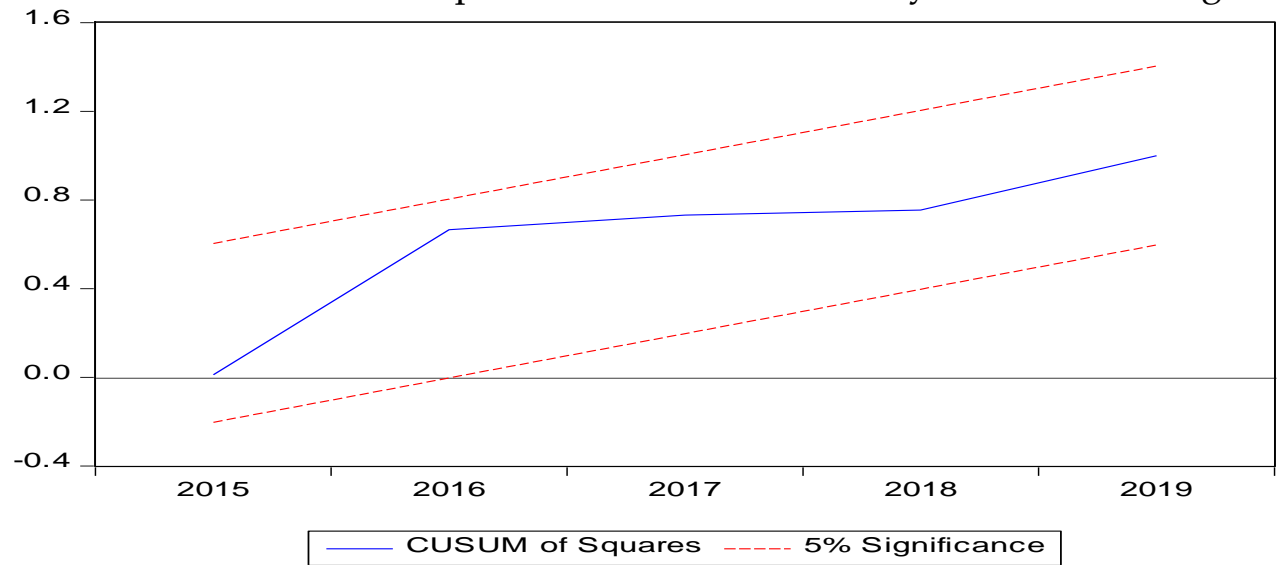

The respective econometric diagnostic tests performed above in Table-5 fail to reject the null hypothesis of Jarque-Bera test and conclude that the residuals are normally distributed. Also, the result of Breusch-Godfrey serial correlation test portrays no trace of high-order autocorrelation. In the same vein, the diagnostic result of Breusch-Pagan test displays evidence of no Heteroscedasticity; similarly, the result of Ramsey RESET test indicates that there is no act of model misspecification error. More so, the parameters stability test conducted via CUSUM and CUSUM of squares tests (Figure 5a and 5b) above indicate that the parameters of the estimated model are within the critical bounds at a significant level of $5 \%$ suggesting that the estimated model is dynamically stable and the estimated results are reliable and satisfactory for policy recommendation.

\section{Conclusion and Policy Recommendation}

The impact of macro-economic behaviour on deposit money bank's liquidity has rarely been found in existing literature investigation. Nevertheless, there is dearth of knowledge as to how interaction of such macroeconomic behaviour affects deposit money bank's liquidity in Nigeria. Consequently, this study extended the frontiers of knowledge in this perspective by investigating how the impact of such macroeconomic behaviour affects DMB'S liquidity in Nigeria. This objective was achieved by using the ARDL-Bounds testing approach for the analysis of annual time-series data from 1990-2020 -- after 
achieving stationarity of the series. To accomplish this task, our model was anchored on Keynesian liquidity theory which sees liquidity as an attribute to an asset - to the theory the more quickly an asset is converted into money the more liquid it is said to be. Based on the bounds testing, there was evidence that the predictor variables moved in the same direction in the long-run and that this movement significantly affected deposit money bank's liquidity in Nigeria. In addition, estimated results showed that current level of money supply (M2) exerted negative impact on deposit money bank's liquidity (LQR) by $13.44 \%$ which was significant in the short-run and insignificant in the long-run. However, the one-year lag and two-year lag of money supply reported positive but insignificant impact on bank liquidity in both long-run and short-run by $2.93 \%$ and $2.27 \%$ respectively. Whilst the third-year lag showed that money supply significantly had $6.17 \%$ negative impact on bank liquidity in the short-run while in the long-run it insignificantly had negative impact on bank liquidity. More so, the empirical result displayed that the current level of exchange rate (EXCHR) significantly promoted DMB's liquidity in the long-run and short-run by $4.04 \%$. Similar results were reported that the one-year lag and two-year lag of exchange rate significantly and positively increased liquidity ratio as a proxy for deposit money bank liquidity by $2.53 \%$ and $2.10 \%$ in both long-run and shortrun respectively. The estimated result displayed that the current level of credit to private sector (CPS) had a significant and positive impact of $2.31 \%$ on deposit money bank liquidity as measured by liquidity ratio (LQR) in the long-run and short-run respectively. Whereas, one-year lag, two-year lag and three-year lag of short-run results indicated credit to private sector had a negative but significant impact on deposit money bank liquidity by $2,80 \%, 1.49 \%$ and $1.46 \%$ in the short-run but negatively insignificant in the long-run. Additionally, the estimated results revealed that the current level of real interest rate (R_INTR) negatively and significantly impacted the deposit money bank liquidity by $10.84 \%$ in both long-run and short-run respectively. Conversely, different results were reported that in the one-year and two-year period real interest rate negatively but significantly impacted the DMB liquidity as a proxy for liquidity ratio (LQR) by $22.61 \%$ and $12.38 \%$ respectively. The coefficient of co-integrating equation portrayed a moderately fast adjustment speed parameter of $3.17 \%$ convergence to longrun equilibrium after a shock. While the parameter stability and robustness checks proved that the estimated parameters of the model are structurally and dynamically stable. Based on the results of our findings, recommendations are set out for policy view; the monetary authority (CBN) should device its policy tool to reduce liquidity (reserve requirement) so as to increase growth rate of money supply in the economy. This would make DMBs to use their expansionary measures to help pump more money in the system. Furthermore, government (central bank) should set and maintain official exchange rate policy; to be properly guided as such would ensure stable atmosphere. Moreover, more liquid assets should be encouraged to increase in Banks' vault as such when converted to cash can be given out as loan - credit to private sector. These indications are demonstrated by the long-run and short-run results of this study. Meanwhile, the monetary authorityCBN should loosen monetary policy; this will make money available in the system by 
buying treasury securities and lowering the reserve requirement at banks. So that interest rate will be low, hence this will enable people, businesses to borrow more and invest.

\section{Conflict of Interest Statement}

The authors did not receive funding from any individual, institution, organisation or group for the purpose of this research study. Hence, the study design, method of data collection and analysis were not influenced by anybody of any kind.

\section{About the Author(s)}

Topbie, Joseph Akeerebari, who is the corresponding author to this manuscript, is a M.Sc. student of Economics at the University of Port Harcourt, whose area of concentration focuses on Monetary/Quantitative Economics. His research interests cut across all branches of economics. His career goal is to contribute positively to designed macroeconomic policies in Nigeria, low-income countries including Sub-Saharan African economies.

\section{References}

Abuzar Eljelly (2004). Liquidity - profitability trade-off: An empirical investigation in an emerging market: International Journal of Commerce and Management 14(2):48-61. DOI:10.1108/10569210480000179

Acharya, V., and Naqvi, H. (2012). The seeds of a crisis: A theory of bank liquidity and risk taking over the business cycle. Journal of Financial Economics, 106(2), 349-366.

Allen N. Berger and Christa Bouwman, (2009). Bank Liquidity Creation. Review of Financial Studies, 2009, vol. 22, issue 9, 3779-3837

Allen, F., and Gale, D. (2000). Bubbles and crises. The Economic Journal, 110(1), 236-255.

Barlevy, G. (2014). A leverage-based model of speculative bubbles. Journal of Economic Theory, 153(1), 459-505.

Barry Eichengreen and Poonam Gupta (2013). The Real Exchange Rate and Export Growth: Are Services Different? Bank of Korea WP 2013-17

Basel Committee on Banking Supervision (2008). Principle for sound liquidity risk management. Bank for International Settlements.

Bassey, G. E., Tobi, E. G., Bassey, I. F., and Ekwere, R. E. (2015). Liquidity Management and the Performance of Banks in Nigeria (2000-2010). International Journal of Academic Research in Accounting, Finance and Management Sciences, 6(1), 41-48.

Benjamin S. Wilner (2000). The Exploitation of Relationships in Financial Distress: The Case of Trade Credit. The Journal of The American Association: https://doi.org/10.1111/0022-1082.00203

Berger, A. N., and Bouwman, C. H. S. (2009). Bank liquidity creation. Review of Financial Studies, 22(9), 3779-3837. 
Björn Imbierowicz and Christian Rauch (2014). The relationship between liquidity risk and credit risk in banks. Journal of Banking $\mathcal{E}$ Finance Volume 40, March 2014, Pages 242-256

Bonfim, D., \& Kim, M. (2012). Liquidity Risk in Banking: Is There Herding. European Banking Center Discussion Paper No. 2012-024. https://doi.org/10.2139/ssrn.2163547

Bonner, C., van Lelyveld, I., and Zymek, R. (2015). Banks' liquidity buffers and the role of liquidity regulation. Journal of Financial Services Research, 48(3), 215-234.

Clemens Bonner (2016). Preferential Regulatory Treatment and Banks' Demand For Government Bonds. Journal Of Money, Credit And Banking Volume 48, Issue 6 P. 1195-1221. https://doi.org/10.1111/jmcb.12331

Dahir, A. M., Mahat, F. B., and Ali, N. A. B. (2017). Funding liquidity risk and bank risktaking in BRICS countries: An application of system GMM approach. International Journal of Emerging Markets, 13(1), 231-248.

David A. Dickey. "Stationarity Issues in Time Series Models" (PDF). 2.sas.com. Retrieved 2016-06-26

Delechat Corinne, Camila H. A., Priscilla S. M. and Svetlana V. (2012). The Determinants of Banks' Liquidity Buffers in Central America. IMF Working Papers 12(301) DOI:10.5089/9781616356675.001

Diamond, D. W. (1984). Financial intermediation and delegated monitoring. The Review of Economic Studies, 51(3), 393-414.

Dimand, Robert W. (2008). "Macroeconomics, origins and history of". In Durlauf, Steven N.; Blume, Lawrence E. (eds.). The New Palgrave Dictionary of Economics. Palgrave Macmillan. pp. 236-244. doi:10.1057/9780230226203.1009. ISBN 978-0-333-786765.

Fuller, W. A. (1976). Introduction to Statistical Time Series. New York: John Wiley and Sons. ISBN 0-471-28715-6

Gauti B. Eggertsson (2008). "Liquidity trap," The New Palgrave Dictionary of Economics, 2nd Edition.

Gerlach, S. and Wensheng P. and Chang S. (2005). "Macroeconomic conditions and banking performance in Hong Kong SAR: a panel data study,"BIS Papers chapters, in: Bank for International Settlements (ed.), Investigating the relationship between the financial and real economy, volume 22, pages 481-97, Bank for International Settlements.

González-Hermosillo, B. (1999). Developing indicators to provide early warnings of banking crises. Finance and Development, 36, 36-39.

González-Hermosillo, Brenda (1999). Determinants of Ex-Ante Banking System Distress: A Macro-Micro Empirical Exploration of Some Recent Episodes (March 1999). Available at SSRN: $\underline{\text { https://ssrn.com/abstract }=880560}$ or http://dx.doi.org/10.2139/ssrn.880560.

Han Hong, Jing-Zhi Huang and Deming Wu (2014). The information content of Basel III liquidity risk measures. Journal of Financial Stability 15:91-111 DOI:10.1016/j.jfs.2014.09.003 
Holmström, B., and Tirole, J. (1998). Private and public supply of liquidity. Journal of Political Economy, 106(1), 1-40.

Ibe, S. O. (2013). The Impact of Liquidity Management on the Profitability of Banks in Nigeria. Journal of Finance and Bank Management,1 (1), 37-48. Retrieved from http://jfbmnet.com/journals/jfbm/Vol 1 No 1 June 2013/4.pdf

Irina Bunda, Jean-Baptiste Desquilbet (2003). Bank Liquidity and Exchange Rate Regimes. Uni-versity of National and World Economy Sofia, Bulgaria. "Current Challenges, New European Perspectives" 3rd International Scientific Conference, May 2003, Sofia, Bulgaria. pp.24-43, 3rdInternational Scientific Conference Proceedings. $<$ hal00422622>

J. M. Keynes, The General Theory of Employment, Interest and Money (London: Macmillan, 1936).

Kanwal, S and Nadeem, M. (2013). The Impact of Macroeconomic Variables on the Profitability of Listed Commercial Banks in Pakistan. European Journal of Business and Social Sciences, 2(9), 186-201.

Kurotamunobaraomi T., Giami, I. B. and Obari, O. B. (2017). Liquidity and Performance of Nigerian Banks. Journal of Accounting and Financial Management ISSN 2504-8856 Vol. 3 No. 12017 www.iiardpub.org IIARD - International Institute of Academic Research and Development Page 34

Laeven, Luc A., Risk and Efficiency in East Asian Banks (December 1999). Available at SSRN: https://ssrn.com/abstract $=629192$

Liman Mairafi, Sallahuddin Hassan and Shamsul Mohamed-Arshad (2018). An analysis of the literature on Islamic bank risk-taking. Academy of Accounting and Financial Studies Journal 22(Special):1-7

Michael C. Jensen William H. Meckling (1976). Theory of the firm: Managerial behaviour, agency costs and ownership structure. Journal of Financial Economics

Ndoka, S., Islami, M., and Shima, J. (2017). The impact of liquidity risk management on the performance of Albanian Commercial Banks during the period 2005-2015. International Journal of Social Sciences and Education Research, 3(1), 70-76. https://doi.org/10.24289/ijsser.283588

Ongeri, G. (2014). The Effect of Macroeconomic Variables on the Financial Performance of Non-Bank Financial Institutions in Kenya. An unpublished MSc Finance project, university of Nairobi.

Osamwonyi, I and Chijuka, I. (2014). The Impact of Macroeconomic Variables on the Profitability of Listed Commercial Banks in Nigeria. European Journal of Accounting Auditing and Finance Research, 2(10), 85-95.

Petria, N., and Petria, L. (2009). Operational risk management and Basel II. Land Forces Academy Review, 14(4), 96.

Phillips, P. C. B.; Perron, P. (1988). "Testing for a Unit Root in Time Series Regression" (PDF). Biometrika. 75 (2): 335-346. doi:10.1093/biomet/75.2.335

San, O. and Heng, T. (2013). Factors affecting the Profitability of Malaysian Commercial Banks. African Journal of Business Management, 7(8), 649-660. 
Sanusi, S. L. (2010). "The Nigerian banking industry: What went wrong and the way forward." Bayero University, Kano Convocation Lecture. Abuja.

Sanusi, S. L. (2011). Global financial meltdown and the reforms in the Nigerian banking sector. Central Bank of Nigeria Journal of Applied Statistics, 2(1), 93-108.

Simiyu, C and Ngile, L. (2015). Effect of Macroeconomic Variables on Profitability of Commercial Banks Listed in the Nairobi Securities Exchange. International Journal of Economics, Commerce and Management, 3(4)

Soludo, C. C. (2004). Consolidating the Nigerian banking industry to meet the development challenges of the 21st century. Abuja, Nigeria.

Somoye, R. and Ilo, B. (2009). The impact of macroeconomic instability on the banking sector lending behavior in Nigeria. Journal of Money Investment and Banking, 7(2): 45-60.

Talavera, O., Andry, T. and Oleksandr, Z. (2006). Macroeconomic uncertainty and bank lending: The case of Ukraine. German institute for economic research discussion paper series No 637. 1-24.

Vazquez, F., and Federico, P. M. (2015). Bank funding structures and risk: Evidence from the global financial crisis. Journal of Banking and Finance, 61, 1-14.

W. Beveridge, Full Employment in a Free Society (London: HMSO, 1944). Google Scholar

Wagner, W. (2007). The liquidity of bank assets and banking stability. Journal of Banking and Finance, 31(1), 121-139.

Yu Hsing, (2013). Effects of Fiscal Policy and Monetary Policy on the Stock Market in Poland. Economies 1(3):19-25. DOI:10.3390/economies1030019

Zhang, X and Daly, K. (2013). The Impact of Bank Specific and Macroeconomic Factors on China's Bank Performance. Global Economy and Finance Journal, 6(2), 1-25. 
Topbie, Joseph Akeerebari; Fiberesima Ibiwari; Nwankwo, Godgift Anyamaobi

IMPACT OF MACROECONOMIC BEHAVIOUR ON DEPOSIT MONEY BANK LIQUIDITY IN NIGERIA

Creative Commons licensing terms

Authors will retain copyright to their published articles agreeing that a Creative Commons Attribution 4.0 International License (CC BY 4.0 ) terms will be applied to their work. Under the terms of this license, no permission is required from the author(s) or publisher for members of the community to copy, distribute, transmit or adapt the article content, providing a proper, prominent and unambiguous attribution to the authors in a manner that makes clear that the materials are being reused under permission of a Creative Commons License. Views, opinions and conclusions expressed in this research article are views, opinions and conclusions of the author(s). Open Access Publishing Group and European Journal of Economic and Financial Research shall not be responsible or answerable for any loss, damage or liability caused in relation to/arising out of conflict of interests, copyright violations and inappropriate or inaccurate use of any kind content related or integrated on the research work. All the published works are meeting the Open Access Publishing requirements and can be freely accessed, shared, modified, distributed and used in educational, commercial and non-commercial purposes under a Creative Commons Attribution 4.0 International License (CC BY 4.0). 